\title{
CYTOKINE AND ANTIBODY PRODUCTION DURING MURINE LEPTOSPIROSIS
}

\author{
MARINHO M. (1), SILVA C. (1), LIMA V. M. F. (2), PEIRÓ J. R. (2),
}

PERRI S. H. V. (2)

(1) Department of Animal Production and Health, Araçatuba School of Dental Medicine, FOA, São Paulo State University, UNESP, Araçatuba, São Paulo State, Brazil; (2) Department for Clinic and Surgery and Animal Reproduction, Araçatuba School of Dental Medicine, FOA, São Paulo State University, UNESP, Araçatuba, São Paulo State, Brazil.

ABSTRACT: The aim of the present study was to investigate the kinetics of humoral and cellular responses during leptospirosis. We observed that the presence of tumor necrosis factor-alpha (TNF- $\alpha$ ) and interleukin-6 (IL-6) was associated with antibody production and bacterial recovery, and the compromising of both TNF- $\alpha$ and IL-6 in the immunopathogenesis of leptospirosis during an experimental infection of BALB/C mice inoculated with Leptospira interrogans serovar Canicola was verified. Results showed higher levels of TNF- $\alpha$ and IL-6 in the initial phase of infection, in which the greatest bacterial clearance was observed. However, when the bacterial recovery was compared with the kinetics of the production of antibodies, the results revealed a kinetics proportionally inverted to antibody production. This fact may be related to some inhibitory factor which could be responsible for the selective suppression of the cellular immune response. We concluded that during leptospirosis there was a greater mobilization of the cellular immune response activity, mainly in the initial phase of the infectious process, for posterior involvement of the humoral response, and that both TNF- $\alpha$ and IL- 6 could be associated with the immunopathogenesis of the disease.

KEY WORDS: cytokines, cellular immune response, BALB/c mice, leptospirosis.

\section{CORRESPONDENCE TO:}

MÁRCIA MARINHO, Rua Clóvis Pestana, 703, Bairro Dona Amélia, 16050-690, Araçatuba, São Paulo, Brasil. Email: mmarinho@fmva.unesp.br. 


\section{INTRODUCTION}

Leptospirosis is an infectious disease caused by Leptospira interrogans (8). Immunity to this infection is mainly humorally mediated and involves opsonization of leptospires for phagocytosis by macrophages and neutrophils (6). The role of TNF- $\alpha$ in the inflammatory response that occurs during endotoxemia and sepsis has been extensively investigated $(3,9)$. Levels of TNF- $\alpha$ have been detected in the circulation of patients with leptospirosis, an infection caused by spirochetes that have lipopolysaccharide-like material in their cell walls (2). Tajiki et al. (8) found an association between levels of TNF- $\alpha$ and severity of the disease as well as mortality among leptospirosis patients.

We had previously demonstrated (5) the role of cytokines, $\mathrm{NO}$ and $\mathrm{H}_{2} \mathrm{O}_{2}$ in the immunopathology of leptospirosis in mice genetically selected for low $(L)$ and high $(\mathrm{H})$ antibody production and inbred BALB/c mice. Strains $\mathrm{H}$ and BALB/c presented a higher tendency to Th2 response pattern with greater antibody production, higher degree of lesions, and synthesis of IL-4; L strain showed Th1 response pattern with high IFN production and macrophage activity as well as occurrence of lesions in kidney and liver fragments.

Cytokines are immunomodulatory proteins that help organize the immune response to diverse inflammatory processes including infection. Interleukin-6 (IL-6), tumor necrosis factor- $\alpha$ (TNF- $\alpha$ ), and transforming growth factor- $\beta 1$ (TGF- $\beta 1$ ) are cytokines that have been shown to play a role in the immune response to intracellular pathogens in murine and human models (1).

The aims of the present study were to measure the levels of circulatory TNF- $\alpha$ and IL-6 and to verify the relationship of these cytokines to bacterial recovery and antibody production in BALB/C mice during infection by $L$. interrogans serovar Canicola.

\section{MATERIALS AND METHODS}

\section{Mice and inoculum}

Thirty BALB/c mice, male and female, age ranged from 4 to 8 weeks, were divided into 6 groups of five mice each. Animals were intraperitoneally injected with $1 \times 10^{3}$ Leptospira interrogans serovar Canicola, which was previously cultured in Fletcher medium for 7 days (11). Negative control group was injected with $1 \mathrm{ml}$ Fletcher medium alone. Mice were bled from the retro-orbital plexus on days 2, 7, 14, 21 and 
28 after infection for serum collection; then, microscopic agglutination test (MAT) was carried out, according to the procedures described by the World Health Organization (10), and animals were subject to euthanasia.

\section{Recovery of leptospires}

After euthanasia of infected and control mice, tissue fragments of kidney and liver were aseptically removed, macerated and inoculated into Fletcher medium or tryptose-phosphate-broth (TPB) supplemented with $200 \mu \mathrm{g} / \mathrm{ml}$ 5-fluorouracil (7). Cultures were monitored for 60 days for the presence of leptospires.

\section{Macrophage activation}

Peritoneal macrophages were obtained from the peritoneal cavity of mice. Briefly, $10 \mathrm{ml}$ of iced PBS (phosphate buffered solution) was injected into the upper part of the abdomen. Then, the abdominal cavity was massaged and peritoneal fluid was reaspirated using the same syringe. This procedure was repeated three times. Peritoneal suspension was stored in plastic tubes kept on ice, which were centrifuged for 10 minutes at 1500 rpm. Pellet was washed twice and resuspended in RPMI 1640 (Sigma Co., USA) supplemented with 1\% L-glutamine (Sigma Chemical Co., USA), gentamycin $(0.16 \mathrm{mg} / \mathrm{ml})$ and $10 \%$ heat-inactivated fetal bovine sera. The final concentration was adjusted to $0.2 \times 10^{6}$ cells/well. Then, $0.1 \mathrm{ml}$ of this suspension was added to 96-well flat-bottomed plates (Corning). Cells that were not adherent were removed with RPMI 1640 medium at $37^{\circ} \mathrm{C}$, and the adherent cells were covered with $200 \mu \mathrm{l}$ of the same medium. Cells were cultured in the presence or absence of E. coli lipopolysaccharide (LPS; Sigma Co., USA) and incubated at $37^{\circ} \mathrm{C}$ in $5 \% \mathrm{CO}_{2}$ to observe macrophages activation. After 24 and 48 hours of incubation, supernatants were colleted and stored in aliquots at $-70^{\circ} \mathrm{C}$ for subsequent detection of cytokines.

\section{TNF- $\alpha$ and IL-6 levels determination}

TNF- $\alpha$ and IL-6 levels in the cell culture supernatants were determined using ELISA, as previously described by Haaggans et al. (4) and according to the manufacturer's instructions (Pharmigen). A standard curve was obtained by using preparations of known concentrations of mouse recombinant cytokines (rTNF- $\alpha$ and rIL-6). 


\section{Statistical analysis}

Serologic titers obtained from the BALB/c mice were compared using non-parametric Kruskal-Wallis test for independent variables. To compare the means of cytokine levels, we used analysis of variance with repetition of means and the StudentNewman-Keuls test for multiple comparisons; $p<0.05$ (12).

\section{RESULTS}

\section{Antibody production}

Antibody titers produced by mice after inoculation with a sample of Leptospira interrogans serovar Canicola were expressed as base-10 logarithm (Figure 1). Antibody titers were gradually produced with maximum peaks on the $7^{\text {th }}$ day after inoculation. These values remained constant and high until the $21^{\text {st }}$ day, followed by a decrease on the $28^{\text {th }}$ day.

\section{Recovery of viable leptospires}

Table 1 shows bacterial recovery from kidney and liver fragments in TPB or Fletcher medium at $30^{\circ} \mathrm{C}$. The peak of bacterial recovery occurred on the $7^{\text {th }}$ day after infection in both tissues and media. On the same day, bacterial recovery was $100 \%$ in kidney tissue samples cultured in TPB. Recovery of Leptospira interrogans serovar Canicola from kidney or liver tissues gradually increased. Later, there was a gradual decrease. Our results show that there was a better response to leptospira recovery from kidney than from liver fragments.

\section{TNF- $\alpha$ and IL-6 determination}

Production of IL-6 and TNF- $\alpha$ by BALB/C mice peritoneal macrophage cultures incubated for 24 and 48 hours is shown in Figures 2, 3, 4 and 5.

There was a significant difference between production of IL-6 in the absence or presence of LPS when compared to controls on the $7^{\text {th }}, 14^{\text {th }}, 21^{\text {st }}$ and $28^{\text {th }}$ days after inoculation for both cultures (24 and $48 \mathrm{~h}$ incubation).

A significant difference between production of TNF- $\alpha$ in the absence or presence of LPS was observed on the first days of infection, when compared to the control group. TNF- $\alpha$ levels were high on these first days. Similar data were observed with the 
kinetics of IL-6 production. However, IL-6 production was observed until the $28^{\text {th }}$ day of infection.

No significant differences were observed between cultures regarding incubation time and presence or absence of LPS. These data confirmed the presence of TNF- $\alpha$ and IL-6 as a result of Leptospira infection. The kinetics of both cytokines production was identical and macrophages were activated for both LPS and pathogen.

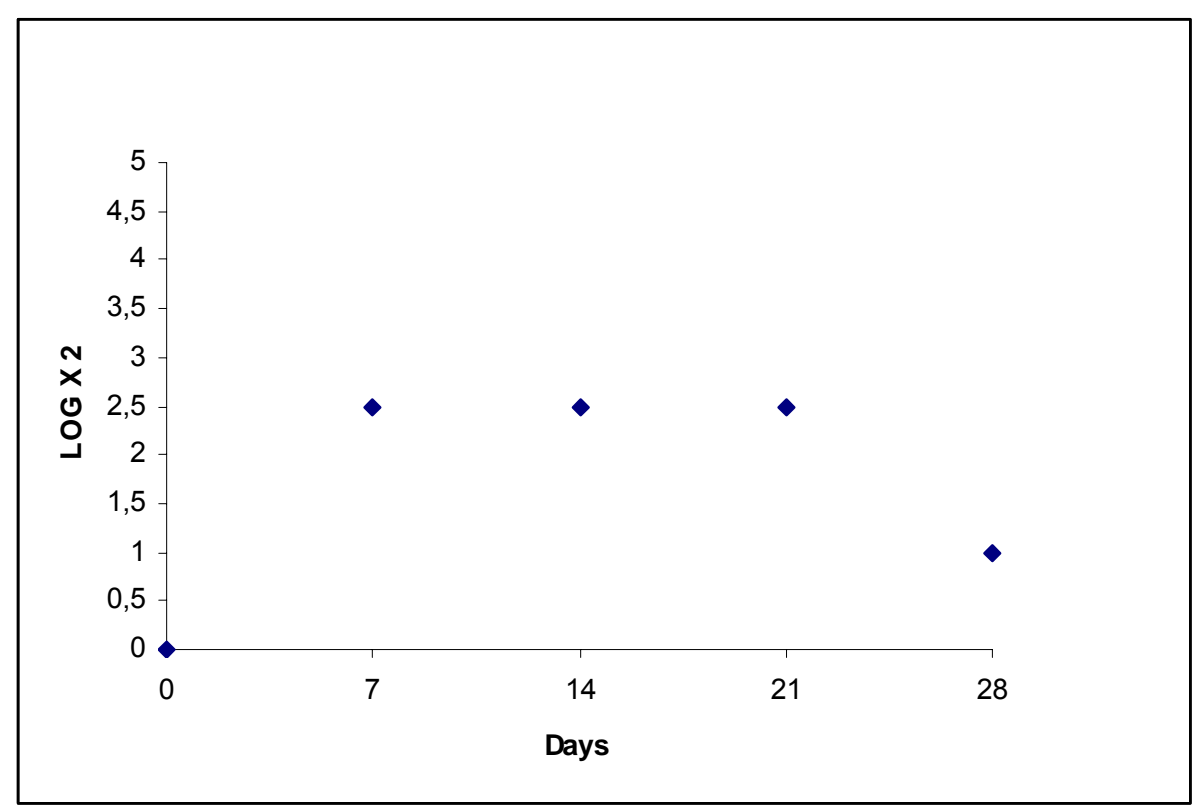

Figure 1. Evaluation of production of antibodies anti-Leptospira interrogans Canicola. Values were expressed as logarithm, according to the Kruskal-Wallis non-parametric test for independent variables $(\alpha=05)$.

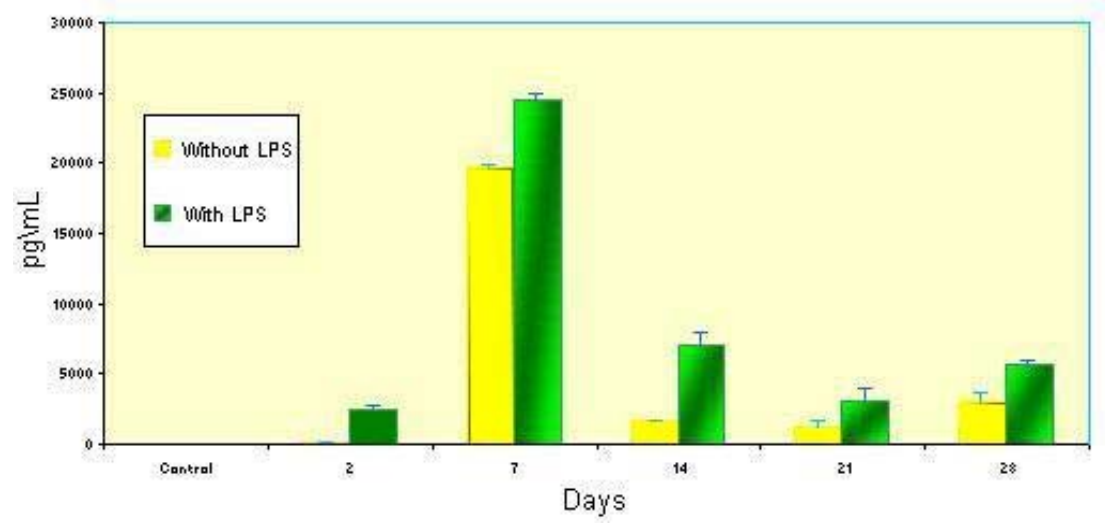

Figure 2. Levels of IL-6 produced by macrophages from BALB/c mice in the absence or presence of LPS in $24 \mathrm{~h}$-incubation culture. Values were expressed as means $\pm S D$. 


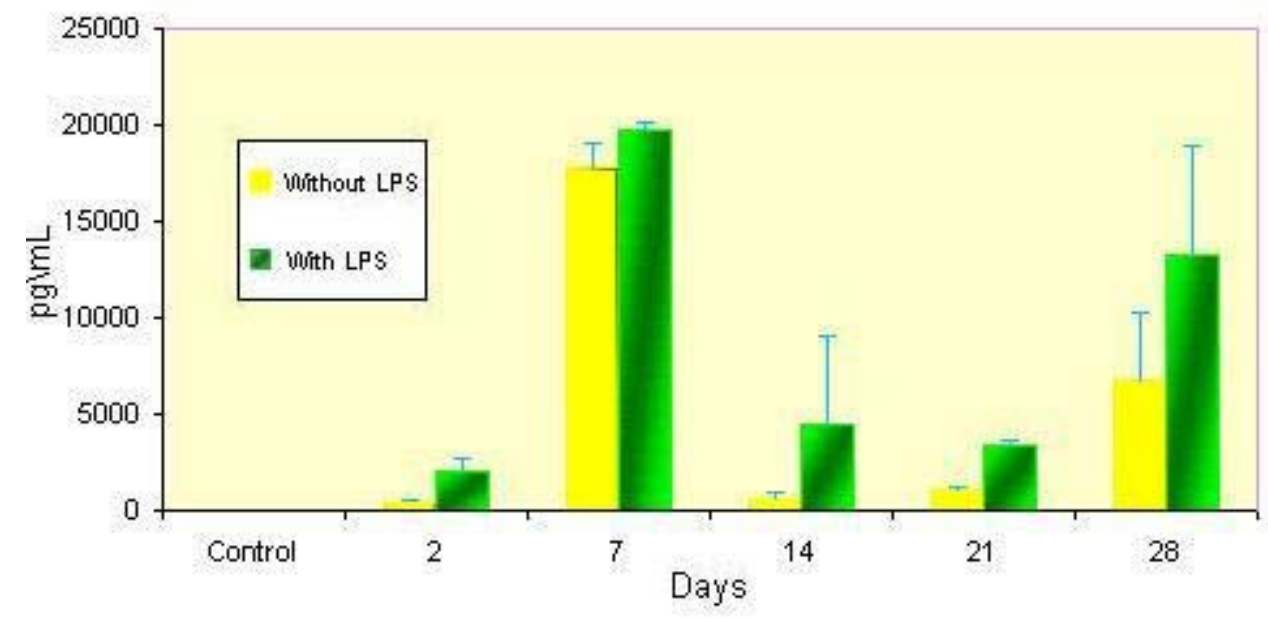

Figure 3. Levels of IL-6 produced by macrophages from BALB/c mice in the absence or presence of LPS in $48 \mathrm{~h}$-incubation culture. Values were expressed as means $\pm S D$.

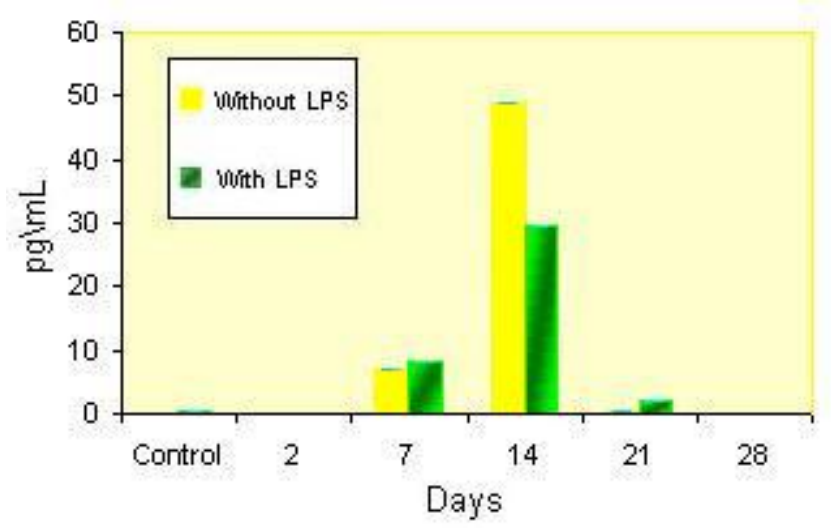

Figure 4. Levels of TNF- $\alpha$ produced by macrophages from BALB/c mice in the absence or presence of LPS in $24 \mathrm{~h}$-incubation culture. Values were expressed as means $\pm S D$.

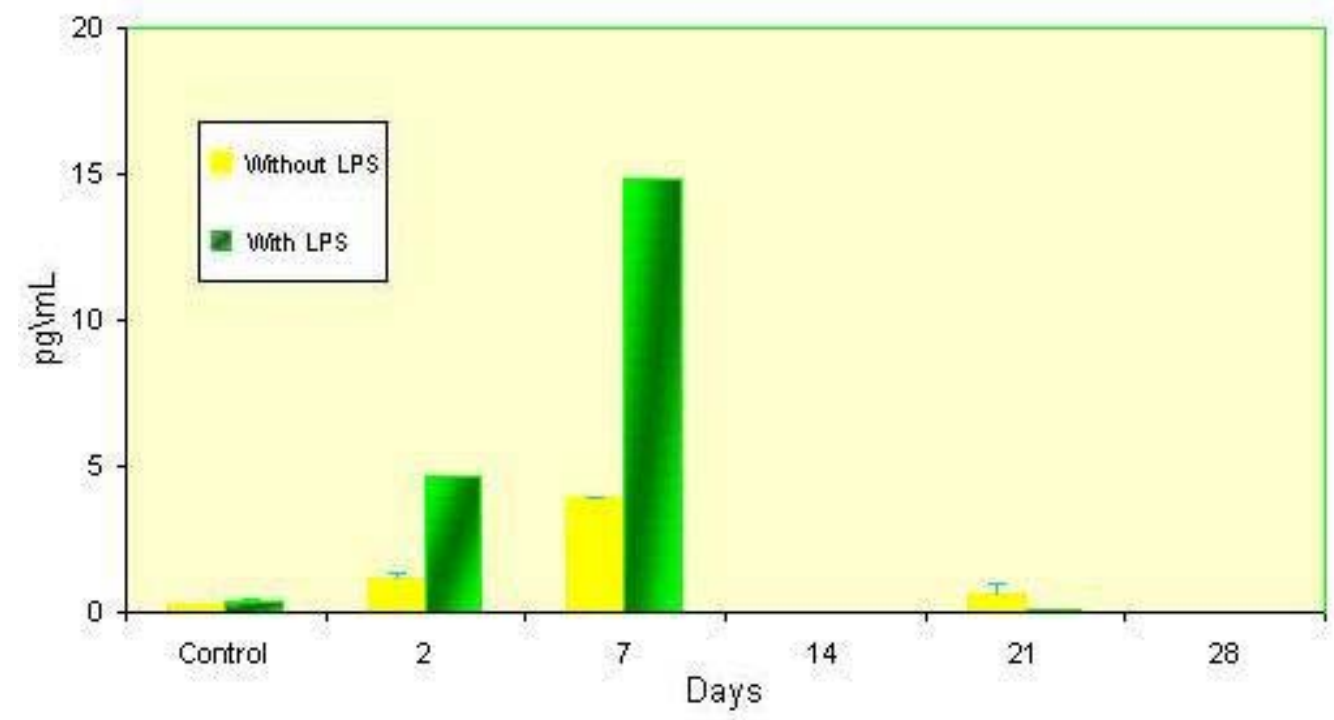

Figure 5. Levels of TNF- $\alpha$ produced by macrophages from BALB/c mice in the absence or presence of LPS in 48 h-incubation culture. Values were expressed as means $\pm S D$. 
Table 1. Recovery of Leptospira interrogans serovar Canicola from kidney and liver fragments in Fletcher medium or Tryptose-Phosphate-Broth (TPB). Values were expressed as percentage.

\begin{tabular}{c|c|c|c|c}
\hline & \multicolumn{2}{|c|}{ KIDNEY } & \multicolumn{2}{c}{ LIVER } \\
\hline Day & $\begin{array}{c}\text { Fletcher } \\
\text { medium }\end{array}$ & TPB & $\begin{array}{c}\text { Fletcher } \\
\text { medium }\end{array}$ & TPB \\
\hline 2 & - & 20 & - & - \\
\hline 7 & 60 & 100 & 60 & 80 \\
\hline 14 & 80 & 20 & - & 20 \\
\hline 21 & 20 & - & 20 & 20 \\
\hline 28 & 40 & 40 & - & - \\
\hline
\end{tabular}

\section{DISCUSSION AND CONCLUSION}

Immunity to leptospirosis is principally humorally mediated and involves opsonization of leptospires for the action of macrophages and neutrophils (6). However, our results showed a mobilization of the cellular immune response mainly in the initial phase of the infection, on the $7^{\text {th }}$ day after inoculation. The peritoneal macrophages activity at that moment was evidenced by the production of TNF- $\alpha$ and IL-6, which reached the maximum peak. Simultaneously, bacterial recovery and antibody production was more evident. When bacterial recovery was compared with the kinetics of the production of antibodies, the results revealed a kinetics proportionally inverted to antibody production. The level of antibodies, at least in part, was a limiting factor to infection, since bacterial clearance occurred after the $28^{\text {th }}$ day, when antibody titers were low.

Marinho et al. (5) studied the role of cytokines, $\mathrm{NO}$ and $\mathrm{H}_{2} \mathrm{O}_{2}$ on the immunopathology of leptospirosis in genetically selected $\mathrm{L}$ and $\mathrm{H}$ antibody producer and inbred BALB/C mice, and demonstrated that $\mathrm{H}$ and BALB/c strains presented a higher tendency to Th2 response pattern with greater antibody production, higher degree of lesions, and synthesis of IL-4. The $L$ strain presented Th1 response pattern with high IFN- $\gamma$ production and macrophages activity as well as occurrence of lesions in kidney and liver fragments.

According to the exposed, we concluded that during leptospirosis there is a greater mobilization of the cellular immune response activity in the initial phase of the infectious process for posterior involvement of humoral response. This fact may 
indicate that some inhibitory factor could be responsible for the selective suppression of the cellular immune response and that both TNF- $\alpha$ and IL-6 could be associated with the disease immunopathogenesis. The kinetics of these cytokines was similar since macrophages were activated for both LPS and pathogen. These data confirmed the mobilization of the cellular immune response. In another experiment, Marinho et al. (5) observed similar results in the production of cytokines using Leptospira interrogans Icterohaemorrhagiae. We suggest that factors related to inflammatory response are associated with the immunopathogenesis of the disease. However, further studies on the immune response to leptospirosis are required.

\section{ACKNOWLEDGEMENTS}

This work was sponsored by the State of São Paulo Research Foundation, FAPESP. Process 2002/10139-1.

\section{REFERENCES}

1 CHAMPSI, J., YOUNG, LS., BERMUDEZ, LE. Production of TNF- $\alpha$, IL-6 and TGF$\beta$, and expression of receptors for TNF- $\alpha$ and IL-6, during murine Mycobacterium avium infection. Immunology, 1995, 85, 549.

2 ESTAVOYER, JM., RACADOT, E., COUETDIC, G., LEROY J., GROSPERRIN, L. Tumor necrosis factor in patients with Leptospirosis. Rev. Infect. Dis.,1991, 13, 1245.

3 GALANOS C, FREUDENBERG M.A., KATSCHING T., SALOMÃO R., MOSSMANN H., KUMAZAWA Y. Tumor necrosis factor and host response to endotoxin. In: RYAN JL, MORRISON DC. Bacterial endotoxic lipopolysaccharides. Vol.II, Immunopharmacology and Pathophysiology. Boca Raton, CRC Press, 1992, 75-1004.

4 HAAGGANS BL., VAN DEN EERTWEGH AJ., CLAASSEN E., HORZINEK MC., SCHIJNS VE. Tumor necrosis factor-alpha production during cytomegalovirus infection in immunosupressed rats. J. Gen. Virol., 1994, 75, 779-87. 
5 MARINHO, M., LANGONI H. OLIVEIRA SL., LIMA VMF., PEIRÓ JR., PERRI SHV., CARREIRA R. Role of cytokines, $\mathrm{H}_{2} \mathrm{O}_{2}$ and $\mathrm{NO}$ on immunopathology of Leptospirosis in genetically selected mice. J. Venom. Anim. Toxins incl. Trop. Dis., 2005, 11, 1-11.

6 MITCHISON, M., BULACH, DM., VINH, T., RAJAKUMAR, K., FAINE, S., ADLER, B. Identification and characterization of the dTDP-Rhamnose biosynthesis and transfer genes of the lipopolysaccharide-related rfb locus in Leptospira interrogans serovar Copenhageni. J. Bacteriol., 1997, 179,1262-7.

7 MYERS, D.M. Manual de métodos para el diagnóstico de laboratório de la leptospirosis. Buenos Aires: Centro Panamericano de Zoonosis/OPS/OMS, 1985. (Nota técnica, 30).

8 TAJIKIH, S.R., SALOMÃO, R. Association of plasma levels of tumor necrosis factor- $\alpha$ with severity of disease and mortality among patients with Leptopirosis. Clin. Infec. Dis., 1996, 23, 1177.

9 VASSALI P. The pathophysiology of tumor necrosis factor. Annu. Rev. Immunol., 1992, 10, 411-52.

10 WORLD HEALTH ORGANIZATION. Current problems in leptospirosis research: report of a WHO expert group. Geneva: WHO, 1967, 32p. (Technical Report Series)

11 YASUDA, P.H. HOSHINO-SHIMIZU, S., YAMASHIRO-KANASHIRO, E.H. DE BRITO, T. Experimental leptospirosis (L. interrogans serovar Icterohaemorrhagiae) of guinea pig: leptospiral antigen, gamma globulin and complement C3 detection in the kidney. Exp. Pathol., 1986 , 29, 35-43.

12 ZAR, J.H Bioestatistical analysis. 3. ed. Upper Saddle River: prentice - Hall, 1996. 718p. 